\title{
Reproductive ecology of the scleractinian coral Echinopora lamellosa in northern and southern Taiwan
}

Received: 28 March 1995/Accepted: 11 April 1995

\begin{abstract}
Sexual reproduction of the scleractinian coral Echinopora lamellosa in Yenliao Bay, northern Taiwan, and in Nanwan Bay, southern Taiwan, was studied from 1990 to 1993 . E. lamellosa is a hermaphroditic broadcast spawner. Gametogenesis takes about 4 to 6 mo and spawning occurs in the summer and fall (July to October). Gametogenesis of the Yenliao Bay population began in April, one month earlier than that of the Nanwan Bay population. Spawning of the Yenliao Bay population occurred in July and August 1991 and August 1992, two months earlier than that at Nanwan Bay in 1991 and in the same month at both sites in 1992. The delayed reproduction of E. lamellosa at the lower latitude (Nanwan Bay) suggests that sea temperature does not operate as a proximate cue for the timing of reproductive activity. The spawning season of the Nanwan Bay population may reflect the environmental conditions favoring the survival of planktonic larvae. The mature egg size $(265 \mu \mathrm{m}$ in 1991 and $251 \mu \mathrm{m}$ in $1992, n=112)$ and colony size at sexual maturity (10.1 to $20.0 \mathrm{~cm}$ in diameter) of the Yenliao Bay population were significantly larger than those of the Nanwan Bay population $(214 \mu \mathrm{m}$ in 1991 and $216 \mu \mathrm{m}$ in 1992 for egg size, $n=112$, and 2.6 to $5.0 \mathrm{~cm}$ for colony size at sexual maturity). The larger egg and colony size at sexual maturity may be related to the unfavorable environment in Yenliao Bay.
\end{abstract}

\section{Introduction}

The majority of scleractinian corals are hermaphroditic broadcast spawners with external fertilization and

Communicated by T. Ikeda, Hiroshima

T.-Y. Fan, C.-F. Dai ( $\bowtie)$

Institute of Oceanography, National Taiwan University,

Taipei, Taiwan 106, Republic of China larval development (Harrison and Wallace 1990; Richmond and Hunter 1990). Most broadcast spawning scleractinians have an annual cycle of gametogenesis that culminates in a brief period of spawning (Harrison and Wallace 1990).

The timing of reproductive activities of marine invertebrates has been related to various environmental factors (Orton 1920; Giese and Pearse 1974). Some studies on scleractinians suggest that seasonal variation in sea temperature may be the major environmental factor controlling the annual cycle of reproduction (Babcock et al. 1986; Harrison and Wallace 1990), while others indicate that photoperiod also may play an important role in determining the timing of reproduction (Kojis 1986; Babcock et al. 1994). However, whether these environmental parameters influence the seasonal reproductive cycle as the proximate cues or the ultimate evolutionary causes is not fully understood. Geographic comparison of the reproductive biology of corals offers an approach of discerning species responses to various environments (Oliver et al. 1988; Babcock et al. 1994), thus it may be possible to obtain clues to the factors controlling seasonal spawning by examining regional variations in reproduction of broadcast spawning species.

Some studies have attempted to investigate the natural variability of reproductive traits in a coral species that inhabits different environments. These studies, mostly focused on brooding species, demonstrate that different reproductive strategies may have evolved at different locations (Kojis and Quinn 1984; Richmond and Jokiel 1984; Richmond 1985; Kojis 1986). However, few attempts have been made to provide detailed information on the latitudinal variations in reproductive traits of broadcast spawning species (Glynn et al. 1991, 1994).

Echinopora lamellosa (Esper, 1795) is a widely distributed scleractinian on many Indo Pacific coral reefs, where it may form large assemblages and dominate certain reef areas (Veron et al. 1977; Sheppard 1980; 
Dai 1993). Little information is available on its reproductive biology other than that it is a hermaphroditic spawner and that it participates in the mass spawning event on the Great Barrier Reef (Willis et al. 1985; Babcock et al. 1986). E. lamellosa has been considered one of the dominant species in coral communities in northern and southern Taiwan (Yang and Dai 1982; Dai 1993). Since environmental conditions between these two localities are different, it provides an opportunity to compare the reproductive traits of a broadcast spawner in different environments. The purpose of this study was to determine what intraspecific differences in reproductive traits exist between two populations of $E$. lamellosa in different environments.

\section{Materials and methods}

Study sites

Populations of Echinopora lamellosa were studied in Yenliao Bay, northern Taiwan $\left(25^{\circ} 02^{\prime} \mathrm{N} ; 121^{\circ} 59^{\prime} \mathrm{E}\right)$, and Nanwan Bay, southern Taiwan $\left(21^{\circ} 55^{\prime} \mathrm{N} ; 120^{\circ} 45^{\prime} \mathrm{E}\right)$ (Fig. 1). Coral communities in Yenliao Bay are characterized by a depauperate scleractinian fauna (ca. 110 species) and are dominated by species of Faviidae, Agariciidae, and Pectiniidae (Yang and Dai 1982). E. lamellosa is usually abundant on the seaward slopes at 8 to $15 \mathrm{~m}$ depth. Monthly mean sea temperatures range from 18.0 to $28.0^{\circ} \mathrm{C}$ and water turbidity is relatively high ( 0.65 to 2.30 NTU). Southern Taiwan is surrounded by welldeveloped fringing reefs inhabited by a rich coral fauna (ca. 230



Fig. 1 Map of Taiwan showing the study sites (*) species) (Dai 1991a). Foliaceous corals such as E. lamellosa and others dominate the protected reef slopes at 15 to $25 \mathrm{~m}$ depth (Dai 1993). The marine environment of Nanwan Bay is influenced by the warm Kuroshio current; the monthly mean sea temperatures vary from 23.5 to $28.0^{\circ} \mathrm{C}$. Water turbidity is usually low $(0.28$ to 1.90 NTU) except after heavy rainfall or typhoons in the summer (June to September) (Dai 1991a).

\section{Gametogenesis}

Coral samples of 10 to 20 large colonies ( $>20 \mathrm{~cm}$ in diameter) were collected monthly from Yenliao Bay and Nanwan Bay from September 1990 to October 1992, except in September 1991, and January and October 1992 in Yenliao Bay. Samples were fixed with $10 \%$ formalin in sea water for at least $24 \mathrm{~h}$, rinsed in fresh water, decalcified in $8 \%$ formic acid, and stored in $70 \%$ alcohol. Tissue samples were dehydrated with increasing concentrations of alcohol, cleared with xylene, and embedded in Paraplast. Serial sections 6 to $8 \mu \mathrm{m}$ thick were prepared and stained with Mayer's hematoxylin and eosin. These slides were examined for gamete development under a compound microscope at magnifications up to $1000 \times$. The length and width of at least ten oocytes in nucleolar section were measured for each colony using a micrometer eyepiece. The monthly variation of oocyte size was used to determine the seasonal patterns of oogenesis. The mature egg size was represented by the average of the oocytes collected prior to gamete disappearance.

Colony size at sexual maturity

Coral samples of various sizes were collected before the predicted spawning, i.e. in June 1993 at Yenliao Bay and in July 1993 at Nanwan Bay. Two diameters perpendicular to one another across the colony center were measured and their average was taken as the diameter of the colony. Samples were fixed, decalcified and then examined at magnification $64 \times$ under a dissecting microscope. Colonies were considered to be sexually mature if oocytes were visible under a dissecting microscope.

Sea temperature

Sea temperatures at 6 to $10 \mathrm{~m}$ depth (on reef surface) at the study sites were measured by divers using a thermometer $\left( \pm 0.5^{\circ} \mathrm{C}\right.$ ) around noon on each sampling day. The seasonal variation of monthly mean sea temperatures at both sites was similar to the temperature data published elsewhere (Yang and Dai 1982; Dai 1991a).

\section{Results}

Gametogenesis

Echinopora lamellosa is a simultaneous hermaphrodite. The oocytes and spermaries are within the mesenteries between the retractor muscles and the mesenterial filaments. Five development stages of gametes were classified according to the histological characteristics and relative sizes of oocytes and spermaries. The stages were: (1) oogonia , (2) developing oocytes, (3) developing oocytes and early spermaries, (4) developing oocytes and spermaries, and (5) mature oocytes and 

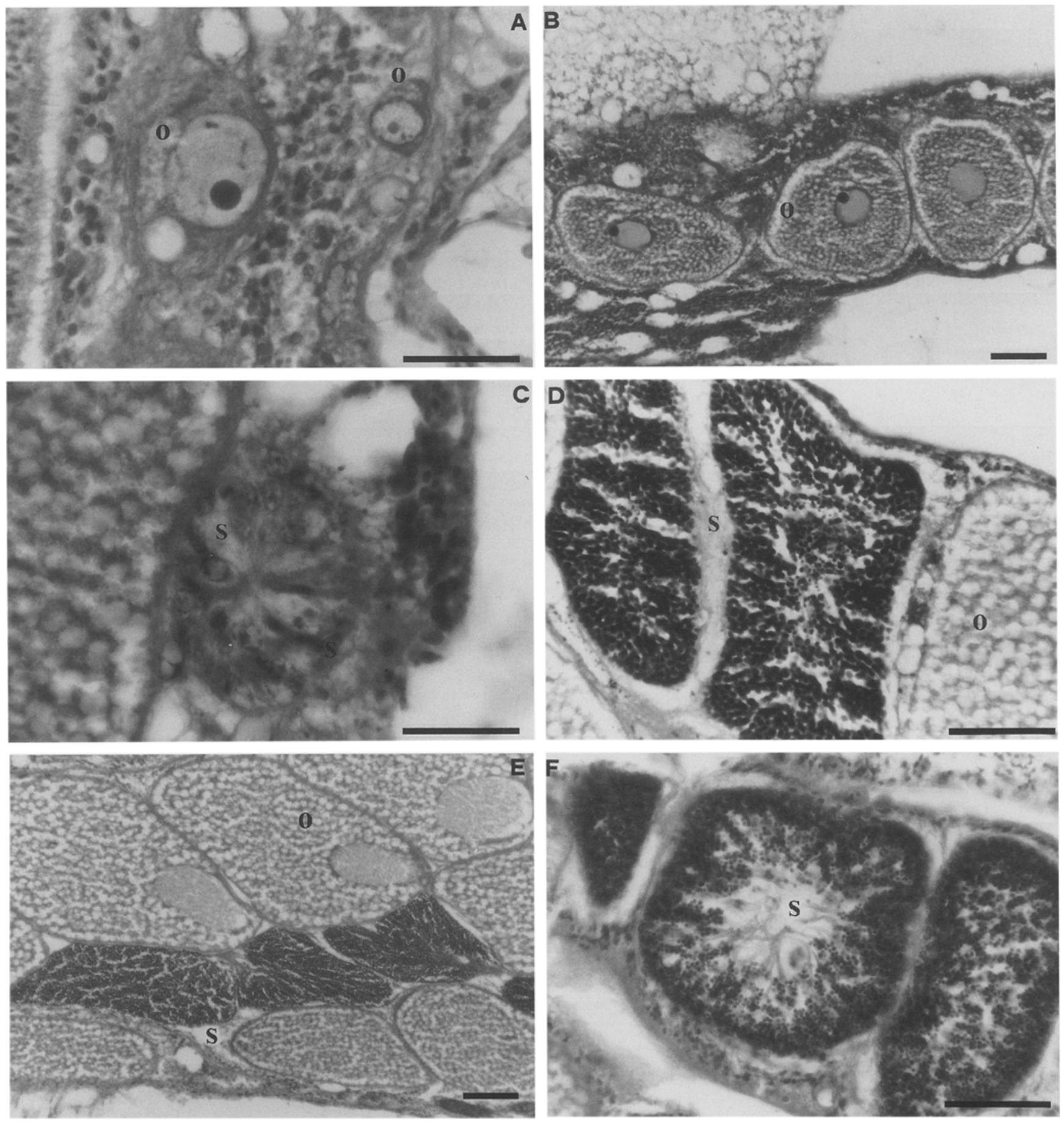

Fig. 2 Echinopora lamellosa. Photomicrographs of histological tissue cross sections showing structure of oocytes and spermaries and sequence of gametogenesis. A Stage 1: oogonia; scale bar $=20 \mu \mathrm{m}$. B Stage 2: developing oocytes; scale bar $=50 \mu \mathrm{m}$. C Stage 3: early spermaries; scale bar $=20 \mu \mathrm{m}$. D Stage 4: developing oocytes and spermaries; scale bar $=50 \mu \mathrm{m}$. E Stage 5: mature oocytes and spermaries; scale bar $=50 \mu \mathrm{m}$. F Stage 5: mature sperm cells; scale bar $=50 \mu \mathrm{m}$. ( $O$ oocytes; $S$ spermaries $)$

spermaries. In Stage 1, few oogonia were found in the mesoglea of the mesenteries and the oogonia were $<50 \mu \mathrm{m}$ in diameter. The oogonium had a nucleus with a prominent nucleolus and a thin layer of cytoplasm (Fig. 2A). In Stage 2, the oogonia underwent vitellogenesis and increased to 50 to $120 \mu \mathrm{m}$ in diameter (Fig. 2B). In Stage 3, the oocytes were 110 to $200 \mu \mathrm{m}$ and the spermaries appeared. The spermaries are composed of several discrete sacs which contain a few spermatogonia (Fig. 2C). In Stage 4, the oocytes 
Fig. 3 Echinopora lamellosa. Seasonal cycle of mean oocyte diameters
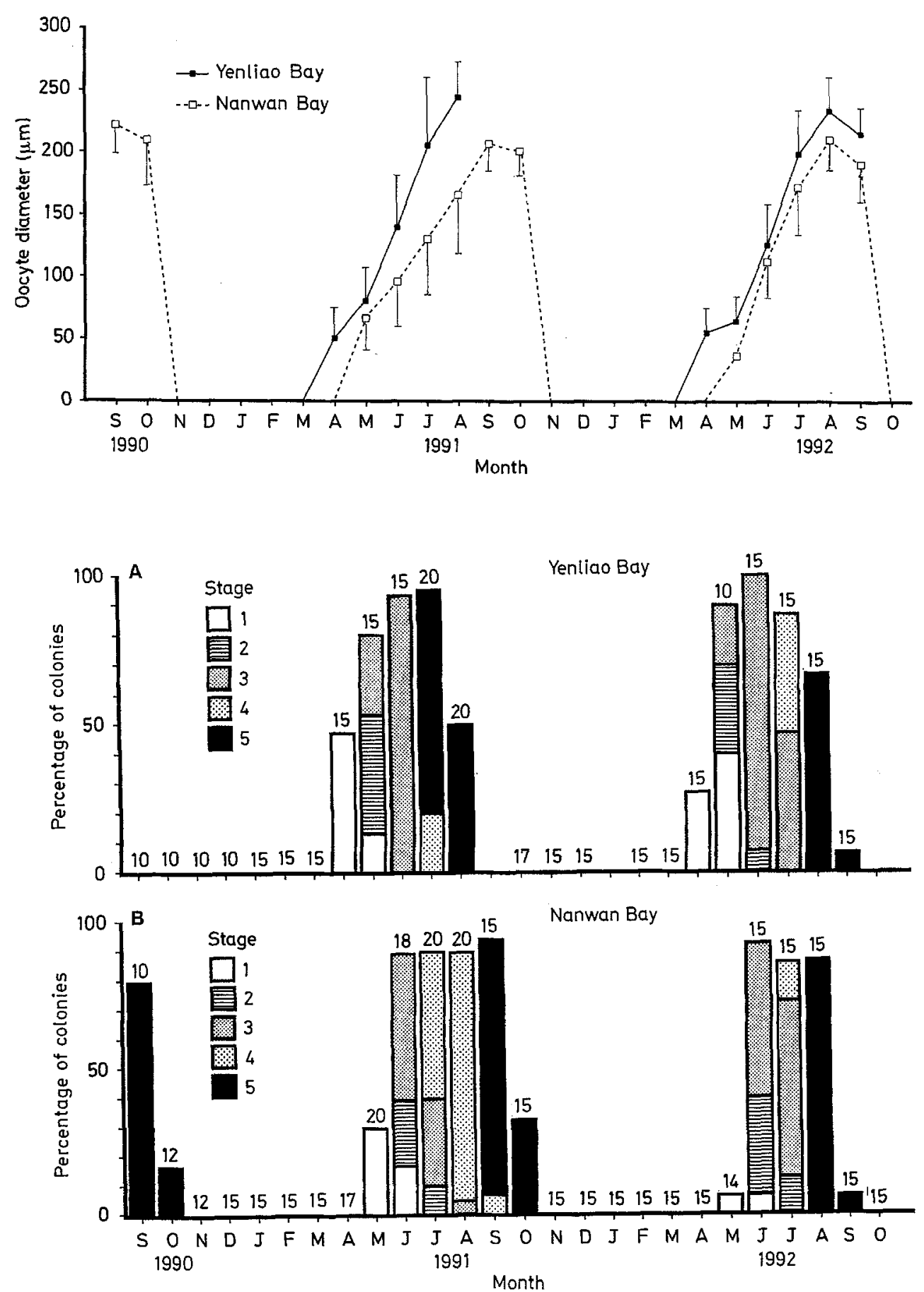

Fig. 4 Echinopora lamellosa. Monthly changes in percentage of colonies containing gametes in A Yenliao Bay, northern Taiwan, and B Nanwan Bay, southern Taiwan. Numbers above bars indicate number of colonies sampled were 150 to $230 \mu \mathrm{m}$ in diameter. The spermaries increased in diameter and contained dense clusters of spermatocytes and spermatids (Fig. 2D). In Stage 5, the mature oocytes reached a diameter of 200 to $290 \mu \mathrm{m}$ (Fig. 2E). The mature spermaries had lumens, and spermatozoa were arranged with the heads located peripherally and the tails projecting toward the lumen (Fig. 2F). Mature eggs were yellow before spawning.
Reproductive seasonality

Monthly changes of mean oocyte diameters and frequencies of colonies containing different stages of gametes in Echinopora lamellosa indicated a clear annual gametogenic cycle (Figs. 3, 4).

In Yenliao Bay, none of the colonies from September 1990 to March 1991 nor from October 1991 to March 
1992 contained gametes (Fig. 3). In 1991 and 1992, oocytes first appeared in April and increased in size until August. Spermatogenesis started in May (Fig. 4A). The percentage of colonies containing gametes increased from April to June and remained high ( > 85\%) until July in 1991 and 1992. The sharp decline of colonies containing gametes in August 1991 and September 1992 was probably a result of spawning.

In Nanwan Bay, none of the colonies contained gametes from November 1990 to April 1991 nor November 1991 to April 1992 (Fig. 3). Oocytes first appeared in May 1991 and 1992, then increased in size from May to September in 1991 and from May to August in 1992. Spermatogenesis started one month later than oogenesis (Fig. 4B). Most colonies (>80\%) contained mature gametes in September 1990, 1991, and August 1992. Mature gametes disappeared in October and November 1990, 1991, and September 1992. The release of gametes probably occurred in September and October 1990 and 1991 and in August 1992.

The results indicate that initiation of gametogenesis of Echinopora lamellosa in Yenliao Bay was 1 mo earlier than in Nanwan Bay, and spawning of the Yenliao Bay population was 1 to 2 mo earlier than that of the Nanwan Bay population in 1990 and 1991 and in the same month at both sites in 1992.

\section{Mature egg size}

Mature egg size of Echinopora lamellosa of the Yenliao Bay population $(265 \pm 24 \mu \mathrm{m}$ in diameter in 1991, $n=112,251 \pm 23 \mu \mathrm{m}$ in $1992, n=112$ ) was significantly larger than that of the Nanwan Bay population $(214 \pm 20 \mu \mathrm{m}$ in $1991, n=112,216 \pm 25 \mu \mathrm{m}$ in 1992 , $n=112$ ) (two-way ANOVA, $p<0.001$; Table 1).

\section{Colony size at sexual maturity}

There was an apparent difference in colony size at sexual maturity of corals from the two sites. Most colonies $(>60 \%)$ of Echinopora lamellosa of the Yenliao Bay population did not contain gametes until reaching a size of 10.1 to $20.0 \mathrm{~cm}$ in diameter (Fig. 5). This size is about four times greater than that of the Nanwan Bay population (2.6 to $5.0 \mathrm{~cm}$ ). The minimum colony size at sexual maturity was 8.8 and $3.5 \mathrm{~cm}$ in diameter for the Yenliao Bay and Nanwan Bay populations, respectively. All colonies larger than $20.1 \mathrm{~cm}$ in diameter were mature at both sites.

\section{Sea temperature}

The annual range of monthly mean temperatures was larger at Yenliao Bay $\left(10.0^{\circ} \mathrm{C}\right)$ than at Nanwan Bay $\left(4.5^{\circ} \mathrm{C}\right)$. The differences of monthly mean temperatures
Table 1 Echinopora lamellosa. Two-way ANOVA for effects of site and year on mature egg diameter (SS sum of squares; $M S$ mean square)

\begin{tabular}{lrrrrl}
\hline Source & \multicolumn{1}{l}{ SS } & \multicolumn{1}{l}{ MS } & \multicolumn{1}{l}{ MS } & \multicolumn{1}{l}{$F$} & \multicolumn{1}{l}{$p$} \\
\hline Site & 201938.9 & 1 & 201938.9 & 380.53 & $<0.001$ \\
Year & 3955.0 & 1 & 3955.0 & 7.45 & $<0.01$ \\
Site $\times$ year & 6990.7 & 1 & 6990.7 & 13.17 & $<0.001$ \\
Error & 235618.3 & 444 & 530.7 & & \\
\hline
\end{tabular}

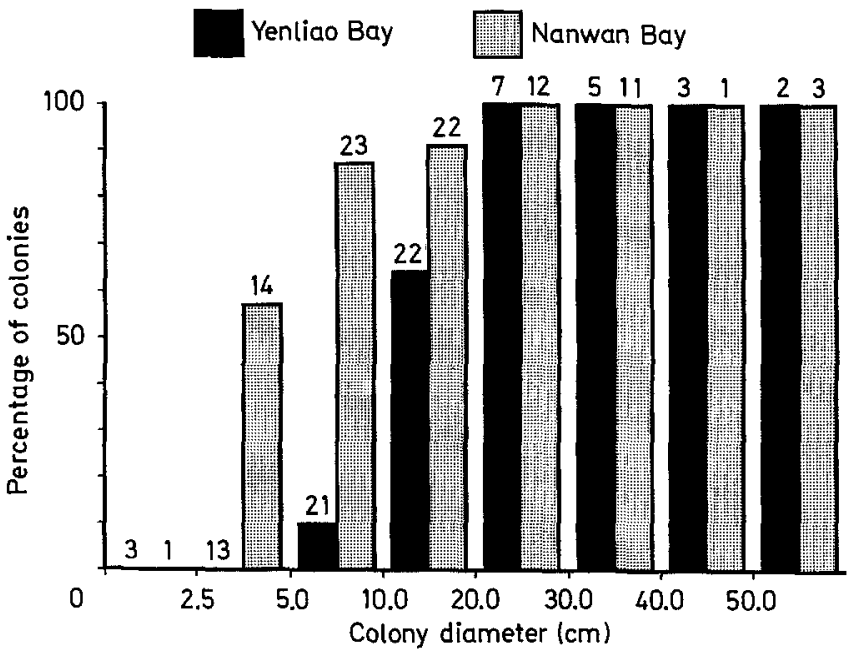

Fig. 5 Echinopora lamellosa. Percentage of colonies with oocytes per size class (mean diameter). Numbers above bars indicate number of colonies sampled

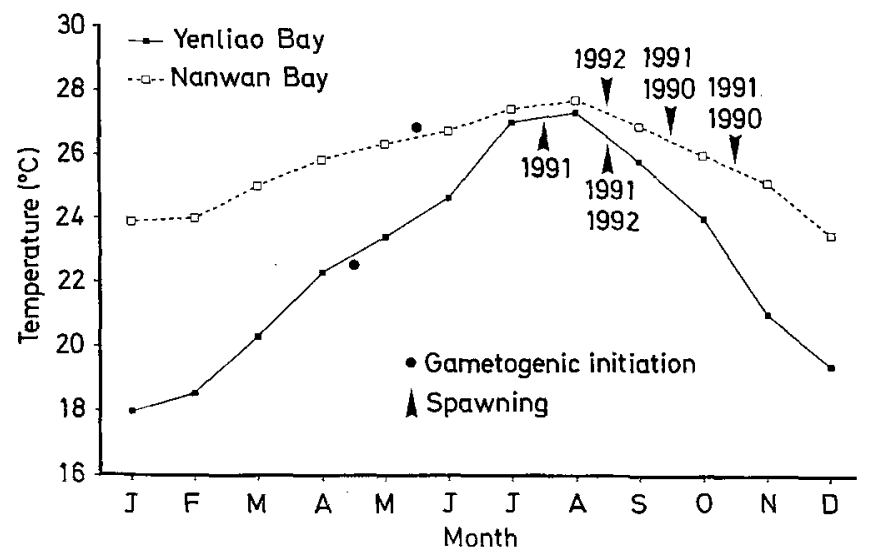

Fig. 6 Seasonal variations of sea temperatures at 6 to $8 \mathrm{~m}$ depth in Yenliao Bay, northern Taiwan, and at 8 to $10 \mathrm{~m}$ depth in Nanwan Bay, southern Taiwan. Spawning periods inferred from histological data. Numbers above and below arrowheads indicate year

between the two sites were the greatest in winter (Fig. 6). Temperature began to rise in February at Yenliao Bay and in January at Nanwan Bay, but reached its peak in August at both sites. The initiation of gametogenesis of Echinopora lamellosa occurred when the sea temperatures were ca. 22.5 and $27.0^{\circ} \mathrm{C}$ for the 




Yenliao Bay and Nanwan Bay, respectively. Spawning occurred during the warmest period of the year at Yenliao Bay, but after the warmest period at Nanwan Bay.

\section{Discussion}

Echinopora lamellosa is a hermaphroditic broadcast spawner with an annual cycle of sexual reproduction. Gametogenesis begins in spring, and spawning occurs in summer or autumn. Reproductive characteristics such as egg size, colony size at sexual maturity, and the timing of reproductive activities of $E$. lamellosa differ between populations from Yenliao Bay in northern Taiwan and Nanwan Bay in southern Taiwan.

Gonad structure of Echinopora lamellosa is similar to that of other faviids from the Indo-Pacific reefs, e.g. Goniastrea australiensis (see Kojis and Quinn 1981), G. aspera (see Babcock 1984), and Favites abdita and Leptoria phrygia (see Kojis and Quinn 1982). In these species, oocytes and spermaries occur within the same mesentery.

Echinopora lamellosa has a shorter period of gametogenesis and smaller egg sizes than other Indo-Pacific faviids studied so far (Table 2). In these species the gametes develop over 6 to 9 mo and the egg sizes range from 350 to $510 \mu \mathrm{m}$ in diameter (Kojis and Quinn 1981, 1982; Harriott 1983; Babcock 1984). However, the period of gametogenesis and egg size of $E$. lamellosa are similar to those of the Atlantic species, Montastrea annularis (see Szmant 1986, 1991; Van Veghel 1994), with gametogenic durations of 4 to $6 \mathrm{mo}$ and egg sizes of $\leq 300 \mu \mathrm{m}$.

The eggs of Echinopora lamellosa from Yenliao Bay were larger than those from Nanwan Bay. Similar latitudinal differences were also found in Pocillopora verrucosa from the Maldives and the Red Sea (Fadlallah 1985; Sier and Olive 1994). The greater egg size of the Yenliao Bay population may reflect an increased investment in larval survivorship and represent a trend of corals in response to unfavorable environment at higher latitudes (Sier and Olive 1994).

Colony size at sexual maturity of Echinopora lamellosa in Yenliao Bay was larger than that in Nanwan Bay (Fig. 5). Studies on recruitment and growth of E. lamellosa colonies in both areas indicated that the minimum age at first reproduction of the Yenliao Bay and Nanwan Bay populations were 5 to 6 and 3 to $4 \mathrm{yr}$, respectively (Fan and Dai unpublished data). The growth rate of small E. lamellosa colonies in Yenliao Bay was lower than that in Nanwan Bay (Fan and Dai unpublished data). Such differences may be related to the relatively unfavorable environment in Yenliao Bay such as lower sea temperature, lower light intensity, and less colonizable substrate. Several studies have demonstrated that adverse environmental conditions 
have a detrimental effect on coral growth (Kojis and Quinn 1984). Since organisms often exhibit trade-off between growth and reproduction (Stearns 1976; Harvell and Grosberg 1988), E. lamellosa in Yenliao Bay seem to initially allocate energy to growth rather than sexual reproduction until they reach larger colony sizes.

Although the sea temperature in Yenliao Bay gets lower and rises later than in Nanwan Bay, spawning of Echinopora lamellosa in Yenliao Bay was 1 to 2 mo earlier than or in the same month as that in Nanwan Bay. This does not agree with the information available for other Indo-Pacific corals in which latitudinal or regional variations in spawning time have been documented. For example, spawning of Goniastrea australiensis at Heron Island $\left(23^{\circ} \mathrm{S}\right)$ occurred two months earlier than at Lord Howe Island $\left(31^{\circ} \mathrm{S}\right)$ (Kojis and Quinn 1981), and Pocillopora verrucosa spawned several months later at higher latitude than at lower latitude reefs (Fadlallah 1985; Shlesinger and Loya 1985; Sier and Olive 1994). In addition, the mass spawning of scleractinians on the Great Barrier Reefs took place earlier on inshore than on offshore reefs (Harrison et al. 1984; Babcock et al. 1986). The earlier spawning has been attributed to earlier rising of sea temperature at lower latitude and inshore reefs. However, Babcock et al. (1994) recently reported that coral mass spawning occurred in the same month on temperate and tropical reefs of western Australia, despite the difference in seasonal temperature fluctuation between the two regions. The reproductive pattern of $E$. lamellosa is similar to that of the Caribbean coral Montastrea anmularis (Table 2). The spawning season of $M$. annularis has been reported to be uniform through a wide latitudinal range (Soong 1991; Szmant 1991), while Van Veghel (1994) reported that gametogenic initiation and spawning of $M$. annularis took place about one month later at warmer localities such as Curaçao and Bonaire than at colder Caribbean localities. The earlier reproductive seasons of $E$. lamellosa and $M$. annularis on high latitude reefs contradicts the predictions based on the latitudinal variations of sea temperature and photoperiod (Orton 1920; Giese and Pearse 1974). Some locally operating factors may play a more important role in the timing of reproduction.

The timing of reproduction often reflects environmental conditions favorable to the survival of larvae (Giese and Pearse 1974). In comparison with Yenliao Bay, the range of sea temperatures in Nanwan Bay is smaller. This provides a longer period during which sea temperature is suitable for successful reproduction. Under this circumstance, sea temperature might not be an important factor controlling the timing of coral reproduction, and other environmental factors may play a more important role in this activity (Shlesinger and Loya 1985; Soong 1991). Besides sea temperature, the climate of Nanwan Bay is also characterized by typhoons and marked seasonal variations in rainfall (Dai 1991a). The heavy summer rainfall can increase water turbidity and decrease salinity as a consequence of terrestrial run-off. The high frequency of typhoons from June to September often causes considerable disturbance on this reef (Dai 1991a). The spawning of Echinopora lamellosa, coinciding with the end of seasonal disturbances, may increase substrate availability to larvae (Dai 1991b), avoid the high mortality caused by disturbances and allow successful reproduction of $E$. lamellosa in Nanwan Bay. Since other sympatric foliaceous corals, including Merulina ampliata (Ellis and Solander, 1786), Echinophyllia aspera (Ellis and Solander, 1786), and Mycedium elephantotus (Pallas, 1766), also spawned in August and September (Dai et al. 1992; Fan and Dai unpublished data), it is possible that the conditions during these months are favorable for the survival of coral larvae. Therefore, the delay of reproductive activities of these corals in Nanwan Bay may be regarded as an adaptation to the local environment.

Acknowledgements We thank Drs. D.G. Fautin, K. Soong, C.-P. Chen and an anonymous referee for their discussions and comments on the manuscript. We also thank Y.-C. Tsay, M.-C. Lin and D.-S. Chen for their assistance in the field. This study was supported by a grant from the National Science Council, R.O.C. (NSC 81-0209-B002A-502).

\section{References}

Babcock RC (1984) Reproduction and distribution of two species of Goniastrea (Scleractinia) from the Great Barrier Reef Province. Coral Reefs 2: 187-195

Babcock RC, Bull GD, Harrison PL, Heyward AJ, Oliver JK, Wallace CC, Willis BL (1986) Synchronous spawnings of 105 scleractinian coral species on the Great Barrier Reef. Mar Biol 90: $379-394$

Babcock RC, Willis BL, Simpson CJ (1994) Mass spawning of corals on a high latitude coral reef. Coral Reefs 13: 161-169

Dai CF (1991a) Reef environment and coral fauna of southern Taiwan. Atoll Res Bull 354: 1-28

Dai CF (1991b) Distribution and adaptive strategies of alcyonacean corals in Nanwan Bay, Taiwan. Hydrobiologia 216/217: 241-246

Dai CF (1993) Patterns of coral distribution and benthic space partitioning on the fringing reefs of southern Taiwan. Mar Ecol Naples 14: 185-204

Dai CF, Soong K, Fan TY (1992) Sexual reproduction of corals in northern and southern Taiwan. Proc 7th int coral Reef Symp 1: 448-455 [Richmond RH (ed) University of Guam, Mangilao, Guam]

Fadlallah YH (1985) Sexual reproduction in Pocillopora verrucosa at Yanbu, Saudi Arabia. Proc 5th int coral Reef Congr 4: 313-318 [Gabrié C et al. (eds) Antenne Museum-EPHE, Moorea, French Polynesia]

Giese AC, Pearse JS (1974) Introduction: general principles. In: Giese AC, Pearse JS (eds) Reproduction of marine invertebrates. Vol 1. Academic Press, New York, pp 1-49

Glynn PW, Colley SB, Eakin CM, Smith DB, Cortés J, Gassman NJ, Guzmán HM, Del Rosario JB, Feingold JS (1994) Reef coral reproduction in the eastern Pacific: Costa Rica, Panamá, and Galápagos Islands (Ecuador). II. Poritidae. Mar Biol 118: 191-208 
Glynn PW, Gassman NJ, Eakin CM, Cortes J, Smith DB, Guzman HM (1991) Reef coral reproduction in the eastern Pacific: Costa Rica, Panama, and Galapagos Islands (Ecuador). I. Pocilloporidae. Mar Biol 109: 355-368

Harriott VJ (1983) Reproductive ecology of four scleractinian species at Lizard Island, Great Barrier Reef. Coral Reefs 2: 9-18

Harrison PL, Babcock RC, Bull GD, Oliver JK, Wallace CC, Willis BL (1984) Mass spawning in tropical reef corals. Science, NY 223: $1186-1189$

Harrison PL, Wallace CC (1990) Reproduction, dispersal and recruitment of scleractinian corals. Chapter 7. In: Dubinsky $Z$ (ed) Ecosystems of the world. Vol 25. Coral reefs. Elsevier, Amsterdam, pp 133-207

Harvell CD, Grosberg RK (1988) The timing of sexual maturity in clonal animals. Ecology 69: 1855-1864

Kojis BL (1986) Sexual reproduction in Acropora (Isopora) (Coelenterata: Scleractinia). II. Latitudinal variation in $A$. palifer from the Great Barrier Reef and Papua New Guinea. Mar Biol 91: 311-318

Kojis BL, Quinn NJ (1981) Aspects of sexual reproduction and larval development in the shallow water hermatypic coral, Goniastrea australensis (Edwards and Haime, 1857). Bull mar Sci 31: $558-573$

Kojis BL, Quinn NJ (1982) Reproductive ecology of two faviid corals (Coelenterata: Scleractinia). Mar Ecol Prog Ser 8: 251-255

Kojis BL, Quinn NJ (1984) Seasonal and depth variation in fecundity of Acropora palifera at two reefs in Papua New Guinea. Coral Reefs 3: $165-172$

Oliver JK, Babcock RC, Harrison PL, Willis BL (1988) Geographic extent of mass coral spawning: clues to ultimate causal factors. Proc 6th int coral Reef Symp 2: 803-810 [Choat JH et al. (eds) Sixth International Coral Reef Symposium Executive Committee, Townsville, Australia]

Orton JH (1920) Sea-temperature, breeding and distribution in marine animals. J mar biol Ass UK 12: 339-366

Richmond RH (1985) Variations in the population biology of Pocillopora damicornis across the Pacific. Proc 5th int coral Reef Congr 6: 101-106 [Gabrié C et al. (eds) Antenne MuseumEPHE, Moorea, French Polynesia]
Richmond RH, Hunter CL (1990) Reproduction and recruitment of corals: comparisons among the Caribbean, the tropical Pacific, and the Red Sea. Mar Ecol Prog Ser 60: 185-203

Richmond RH, Jokiel PL (1984) Lunar periodicity in larva release in the reef coral Pocillopora damicornis at Enewetak and Hawaii. Bull mar Sci 34: 280-287

Sheppard CRC (1980) Coral cover, zonation and diversity on reef slopes of Chagos atolls, and population structures of the major species. Mar Ecol Prog Ser 2: 193-205

Shlesinger Y, Loya Y (1985) Coral community reproductive patterns: Red Sea versus the Great Barrier Reef. Science, NY 228: 1333-1335

Sier CIS, Olive PJW (1994) Reproduction and reproductive variability in the coral Pocillopora verrucosa from the Republic of Maldives. Mar Biol 118: 713-722

Soong K (1991) Sexual reproductive patterns of shallow-water reef corals in Panama. Bull mar Sci 49: 832-846

Stearns SC (1976) Life-history tactics: a review of the ideas. Q Rev Biol 51: 3-47

Szmant AM (1986) Reproductive ecology of Caribbean reef corals. Coral Reefs 5: 43-54

Szmant AM (1991) Sexual reproduction by the Caribbean reef corals Montastrea annularis and M. cavernosa. Mar Ecol Prog Ser 74: 13-25

Van Veghel MLJ (1994) Reproductive characteristics of the polymorphic Caribbean reef building coral Montastrea annularis. I. Gametogenesis and spawning behavior. Mar Ecol Prog Ser 109: 209-219

Veron JEN, Pichon M, Wijsman-Best M (1977) Scleractinia of eastern Australia. Part II. Families Faviidae, Trachyphylliidae. Monogr Ser Aust Inst mar Sci 3: 183-187

Willis BL, Babcock RC, Harrison PL, Oliver JK, Wallace CC (1985) Patterns in the mass spawning of corals on the Great Barrier Reef from 1981 to 1984. Proc 5th int coral Reef Congr 4: 343-348 [Gabrié C et al. (eds) Antenne Museum-EPHE, Moorea, French Polynesia]

Yang RT, Dai CF (1982) Coral communities in Yen-liao Bay, Taiwan. Acta oceanogr taiwan 13: 167-180 